\title{
The Epistemological Diversity of CAnadian Sociology
}

\author{
JoSEPH H. MichALSKI
}

Abstract. The current paper presents the results of a national survey of 190 full-time members of Canadian sociology departments to examine the state of the discipline in 2014-15. The paper focuses on the extent of epistemological diversity in an effort to answer two key questions. First, what intellectual perspectives prevail among Canadian sociologists and, along these lines, does any particular perspective hold greater prominence? Second, what might explain the variation in the epistemological stances most commonly endorsed? The evidence reveals a preponderance of critical and feminist scholars, which can be explained in large measure by considering the social locations of sociological practitioners. The results of a logistic regression model confirm that gender, generation, geography, and disciplinary genre are significant predictors of critical and critical-feminist orientations. A discussion of qualitative responses fleshes out the dominant themes that Canadian scholars expressed in their survey responses.

Keywords: epistemology, Canadian sociology, survey, paradigms, criticalfeminist core

Résumé. Le présent article présente les résultats d'une enquête nationale menée auprès de 190 membres à temps plein de départements de sociologie canadiens afin d'examiner l'état de la discipline en 2014-2015. L'article met l'accent sur l'étendue de la diversité épistémologique dans un effort pour répondre à deux questions clés. Premièrement, quelles perspectives intellectuelles prévalentelles chez les sociologues canadiens et, en ce sens, une perspective particulière occupe-t-elle une place plus proéminente? Deuxièmement, qu'est-ce qui pourrait expliquer la variation dans les positions épistémologiques les plus couramment adoptées? L'analyse révèle une prépondérance des chercheurs critiques et féministes, ce qui peut s'expliquer en grande partie en tenant en considération les positions sociales des sociologues. Les résultats d'un modèle de régression logistique confirment que le genre, la génération, la position géographique et la catégorie disciplinaire sont des prédicteurs significatifs des orientations critiques et critique-féministes. Une discussion des réponses 
qualitatives analyse les thèmes dominants que les chercheurs canadiens ont exprimés dans leurs réponses à l'enquête.

Mots-clés: épistémologie, sociologie canadienne, enquête, paradigmes, noyau critique-féministe

\section{INTRODUCTION}

The editors launched the Canadian Journal of Sociology (CJS) in 1975

$\checkmark$ as an inclusive scholarly publication to reflect the increased intellectual pluralism within the discipline. The journal's founders explained that they "deliberately invited sociologists with a wide range of theoretical and methodological persuasions to serve as associate editors" (Ericson et al. 1975: vi). The journal thereby aimed to embrace epistemological diversity as opposed to the perceived positivistic hegemony of leading U. S. publications. Such an approach resonated quite well with a generation of sociologists who had honed their intellectual chops during the 1960s and as the academy's doors opened up to a more heterogeneous professoriate and student population.

By the 1970s, scholars acknowledged the epistemological and theoretical pluralism within the discipline, rooted in a range of philosophical assumptions that sociologists espoused (Ritzer 1975; Turner 2001). While Canada continued to draw heavily upon European and American sociological approaches, the publication of Canadian academic journals, the institutionalization of independent departments of sociology, the soaring growth of Canadian higher education, and the establishment of Ph.D. programs helped foster a degree of intellectual indigenization (Clark 1975; Hiller 1980; Helmes-Hayes and McLaughlin 2009). Several macro-sociological, feminist, critical, and interpretive scholars ascended to prominence within Canada, ensuring a variegated discipline infused with distinctive Canadian perspectives (Felt 1975; Smith 1975; Clement 1977; Clark 1979; Hiller 1979; Luxton 1980). The subsequent emergence of post-modernist critiques and cultural studies sounded the death knell for any presumptions of a monolithic approach to social scientific analysis (Morrow 1991; Nielsen 1991; Andrew 1995).

The ensuing theoretical and methodological potpourri has generated much discussion regarding disciplinary divisions (see Haynor and Varacalli 1993; Bakker 2011), as well as the degree to which Canadian sociology should maintain a certain intellectual autonomy in the face of globalization (Curtis and Weir 2002; Platt 2006; Michalski 2008; Gingras 2010; Matthews 2014). Yet only limited empirical work has investigated these issues. The current paper, therefore, draws upon a national study of Canadian sociologists to examine two questions. First, what 
constellation of epistemological perspectives prevails among Canadian academicians currently teaching in sociology departments, as indicated by their self-described methodological, theoretical, and paradigmatic orientations? Second, what might help explain the variation in epistemological stances most commonly endorsed?

\section{The Sociological Context of Epistemological Diversity}

Science as a truth system has evolved as philosophers have deconstructed core assumptions and logics, historians have documented key developments, and practitioners have refined their methods for investigating reality. ${ }^{1}$ One dominant narrative consists of the metaphysical struggle to reconcile the Kantian and Cartesian tensions between objective and subjective reality. The ontological and epistemological issues involve normative discussions as to the validity of various representations of reality and the ideal strategies through which a cumulative body of knowledge should be generated (Fuchs 1993; see Giri 2006). Much of the debate has centered on specifying criteria upon which universal scientific truth claims might be established as distinct from non-scientific claims. Yet no such Archimedean fulcrum exists from which to gaze upon the social world to evaluate the absolute quality of truth claims, even within science-which some view as socially constructed (Cole 2006) or as essentially another literary genre (Rorty 1991).

The epistemological problem cannot be settled through empirical assessment. In fact, Rosenberg (1986: 341) has argued that the "purely epistemological exploration of the strengths and weaknesses of alternative theories of knowledge will neither come to any philosophical consensus, nor will it advance social science in the slightest." Rather, as Fuchs (1993) explains, competing epistemologies underscore the common beliefs of different groups who claim to be engaged in science. He argues epistemologies should be characterized as social ideologies that inform scientific practices, deriving from the various sets of ontological and methodological assumptions that practitioners share (see Latour 1987). ${ }^{2}$ By sociologizing epistemology, then, one arrives at a rather different question compared to the usual philosophical concerns: what ex-

1. The contours of the main arguments can be found in selected prominent works such as Popper (1934), Gouldner (1970), Feyeraband (1975), Rorty (1979), Laudan (1990), and Fuller (1993).

2. Collins (2000: 252) defines epistemology as "an overarching theory of knowledge (of) the standards used to assess knowledge or why we believe what we believe to be true." Paradigms refer to conceptual frameworks used to interpret the knowledge produced, while methodologies refer to the mechanics of how one conducts research within particular scholarly traditions. 
plains the variable nature of epistemological views held by social science practitioners? ${ }^{3}$

Regardless of one's perspective, the social sciences have been subjected to substantial reevaluation over the past half century, as scholars hold myriad views as to what constitutes a sociological science. ${ }^{4}$ Since epistemological assumptions always underlie theoretical claims, disputes about valid disciplinary knowledge and how that knowledge should be generated are inevitable (Abend 2006; Nash and Wardell 1993). As Patricia Hill Collins (2000: 254) has noted, social groups observe and experience the world differently based upon their distinct social locations: "Just as the material realities of powerful and dominated groups produce separate standpoints, these groups may also deploy distinctive epistemologies or theories of knowledge" (see Smith 2005). As a result, the efforts aimed at epistemological unification as the solution to intellectual fragmentation have not been highly successful. ${ }^{5}$

The evidence instead confirms that intellectual diversity has prevailed for decades within Canadian sociology. In 1985, the Canadian Review of Sociology and Anthropology published a thematic issue to assess theoretical developments in the aftermath of the Canadianization movement (see Cormier 2004, 2005). The issue included articles by prominent scholars who each presented an historical excursus of six paradigms: political economy (Marchak 1985), structuralism (Richardson and Wellman 1985), feminism (Eichler 1985), phenomenology (O’Neill 1985), critical theory (Morrow 1985), and quantitative or positivistic analysis (Hunter 1985). The editor acknowledged that while not exhaustive of Anglo-Canadian paradigms (Québécois sociology was covered in a subsequent volume), these frameworks represented the most eminent perspectives at that time (Jackson 1985). While some critics have bemoaned intellectual fragmentation (Collins 1986; Turner 1989; Turner and Turner 1990; see Phillips 2001), Canadian sociolo-

3. Mannheim ([1929]1966: 265) described the "the social conditioning of knowledge," or, within a Heideggerian framework, all knowledge has a social character (see Tanesini 1999).

4. Space constraints limit detailed critiques of these epistemological orientations and the fierce intellectual debates that have challenged science as a truth system (Ashman and Baringer 2001).

5. Hence Puddephatt and McLaughlin (2015: 327) have argued in favour of maintaining a multi-paradigm sociology, despite the tensions embedded in various aspects of knowledge production: "(I)t is better to celebrate differences rather than striving for conceptual convergence." They conclude their incisive analysis with an entreaty "to embrace the social, political, ontological, epistemological, theoretical, and methodological diversity of Canadian sociology" (p. 329). 
gists in general have embraced disciplinary flexibility and theoretical pluralism (Jackson 1985; McLaughlin 2014; Puddephatt and McLaughlin 2015).

Indeed, epistemological heterogeneity has only increased as theories derived from critical, feminist, postmodernist, cultural studies, standpoint, and intersectionality logics (among others) have proliferated. The many approaches to knowledge production present a classificatory challenge to anyone mapping the intellectual landscape, as any cartographic approach will yield criticism. The disagreements stem mainly from differences in the epistemological stance one uses to interpret evidence. Truth claims are always linked to one's epistemological foundation. ${ }^{6}$

\section{Typologizing Epistemologies}

The mélange of intellectual views reflects various sociohistorical forces that have affected academia. Table 1 offers a brief outline of several key assumptions, aims, and logics of five common epistemological frameworks in the social scientific literature. The typology parallels Neuman's (2006: 105) work in part by identifying differences in ontological assumptions, the nature of valid empirical evidence, explanatory logics, the evaluation of truth claims, rationales for conducting research, and the role of human values in doing research. ${ }^{7}$ Selected influential source materials associated with each framework are referenced in the table's final row.

6. Abend (2006: 28) notes "the epistemological assumptions of one's own claims, the language in which they are written can be said to performatively support a certain way of doing science." In the current study, many participants inquired as to my intellectual persuasion, or noted that they would have framed the issues differently or chosen an altogether different methodology.

7. The characterizations stem from the review of the philosophical and sociological literatures and discussions with academicians. As the survey responses shall demonstrate, most scholars have a reasonably clear sense of their own epistemological positions, even if disagreements persist on some of the specifics or different linguistic devices might be used to convey one's position. 


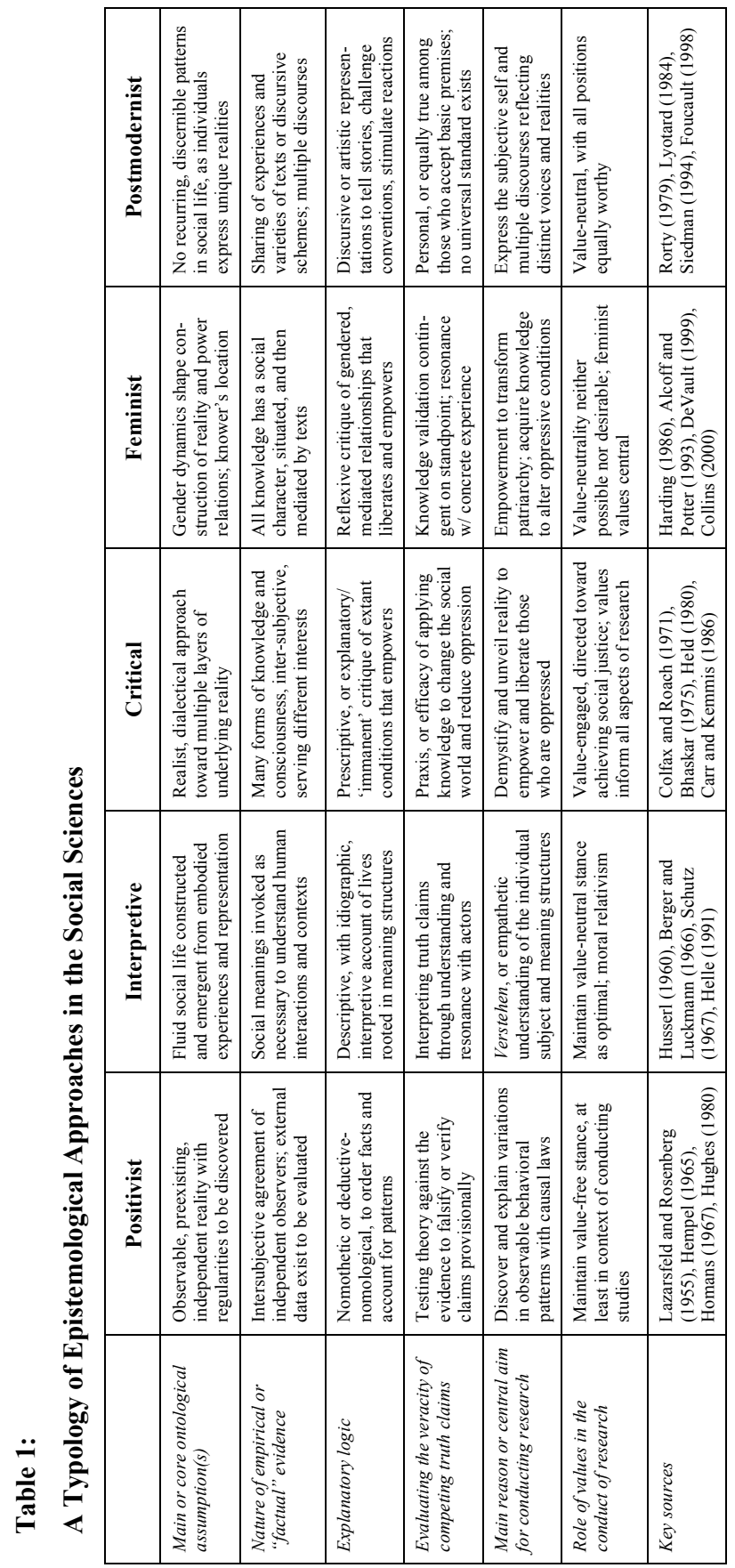


While by no means a definitive outline of the epistemological terrain, the typology highlights two key arguments: 1) whatever one's orientation(s), the core assumptions vary substantially; and 2) academicians of different epistemological stripes nonetheless claim to be staking out scientific or otherwise legitimate knowledge claims. Disciplinary divisions exist because sociological communities disagree as to "the criteria through which they discriminate between true and false claims, their definition of what constitutes knowledge, (and) their understanding of what an acceptable theory should look - that is, their epistemological assumptions" (Abend 2006: 2).

The five approaches include an array of theoretical orientations that are contested within the parameters of each framework. For example, while advocates of pure sociology (Black 1995) and those who prefer the rational choice perspective (Coleman 1990) employ radically different explanatory strategies, both fall squarely within a positivist epistemological framework. ${ }^{8}$ Black (1995: 830), for example, states directly that "I am a scientist. I study variation in reality. As a theoretical sociologist, I seek to order variation in social reality." Black (1995: 847) asks that his work be judged through a scientific lens, insisting critics should " $(\mathrm{t})$ ell me something relevant to what I am trying to accomplish — something scientific." Coleman's (1990: 18) arguments are more abstruse, but he insists that "the theoretical aim of social science must be to conceive of (individual) action in a way that makes it rational from the point of view of the actor." Despite their analytic differences, both theorists favor the development of quantifiable propositions and testable models to examine social behavior.

Those who prefer an interpretive approach start from a different ontological position, emphasizing the hermeneutic aspects of the human condition and the importance of examining the meanings that help frame the social construction of reality (Berger and Luckmann 1966). The interpretive analyst logically calls upon different kinds of evidence to help articulate much more descriptive and experiential accounts of individuals' lived experiences. Rather than explain objective and external patterns of human behavior, interpretive theorists aspire to provide an interpretive understanding of social actors. To explain social action

8. Their explanatory strategies could not be more dissimilar. Black (1995) employs pure sociology to explain how social life varies with the "social geometry" of social space, eschewing references to individuals, their psychological dispositions, and purposive behavior altogether. Coleman's (1990: 13) rational choice approach emphasizes "the same purposive theory of action used in Weber's study of Protestantism and capitalism," i.e., a model that delineates the underlying rationale for why individuals select specific courses of action to achieve their goals. 
requires that one must investigate the sign systems and meanings that individuals attach to their behavior (Helle 1991). Hence Carr and Kemmis (1986: 90) conclude that the purpose of interpretive social science and Verstehen explanations "is not to provide causal explanations of human life, but to deepen and extend our knowledge of why social life is perceived and experienced the way that it is."

Advocates of critical social science often share a realist perspective as to the nature of reality, but emphasize too the deep and often hidden structures of power contradicted by surface realities (Bhaskar 1975). Critical theory developed first through the interpretations of Marxist analysis and capitalist critiques, inspired by the goal of human emancipation. Those who prefer critical approaches tend to reject the fact-value distinction and epistemological stances that offer no bases for evaluating evidence on moral grounds aimed at praxis. Antonio (1981: 332) argues, for example, that the fundamental basis of critical theory can be connected to "immanent critique," or "a means of detecting the societal contradictions which offer the most determinate possibilities for emancipatory social change" (see Adorno 1973; Azmanova 2012a). Critical theory often encompasses the idea that the substructures or economic bases of societies shape consciousness and subjectivity, which are conditioned by prevailing institutional logics and legitimated through emergent structures of domination (Thompson 2014). Finally, most critical theory includes a value-engaged element oriented to achieving social justice for oppressed or disenfranchised groups (Azmanova 2012b; Huttunen and Murphy 2012; García 2015).

As regards feminist epistemology, the gender issue factors in as a key ontological aspect, especially in terms of identifying the knower, the experiential aspects of knowing, and granting the idea that universal knowing cannot be achieved except perhaps via "perception at a distance" (Code 1993; Harding 1986, 1991). At times there are direct parallels with both the critical and interpretive approaches, depending on the nuances of various feminist epistemologies (Alcoff and Potter 1993; Tanesini 1999). Herein one should note the centrality of the "situatedness" of the knower as an embodied subject, influenced by social, historical, and physical locations (Longino 2010). Tensions clearly exist between feminist empiricists and standpoint theorists regarding the appropriate approaches to conceptualizing and evaluating evidence, including

9. In Reed and Alexander's (2009: 34) formulation, "The sociologist, then, comes to her data with a set of theoretical presuppositions, and attempts to arrive at a set of post-suppositions, the latter being the meanings which 'constitute' the social reality that, by interpreting evidence, the sociologist proposes to explain and reconstruct." 
underlying background assumptions and the nature of achieving objectivity through individual experience vis-à-vis the scientific community. Yet most feminist epistemological frames stress the importance of ethical and political values in shaping epistemic practices and interpretations of evidence. Or, as Intemann (2010: 793) has concluded, the diverse approaches to feminism nevertheless "are empiricist, contextualist, and normative social epistemological views," which thereby often intersect with critical epistemologies.

Finally, the postmodernist turn in the social sciences shifted the debate in questioning science as the ultimate arbiter of social reality and by renouncing "scientism" as being "an epistemically privileged discourse" (Siedman 1991: 131). As with each epistemological framework, there are several competing strains, sometimes classified under the rubrics of poststructuralism or cultural studies. Yet these many different species share in common a rejection of positivism as the foundational approach to knowledge-building, along with universal grounds for establishing ultimate truth. Rorty $(1979,1991)$, among others, has argued that the efforts to establish foundational discourses inevitably reflect the local and ethnocentric prejudices of historically- and culturally-bound subjects. Instead, there are multiple discourses, equally valid, bearing the imprimatur of those who are committed to the intellectual, moral, and political consequences of their competing conceptual frameworks (Foucault 1998). With epistemic doubt as the norm, social theory expresses social narratives embracing competing discourses and performances of truth rooted in local values and traditions (Siedman 1994).

\section{Explaining Epistemological Diversity}

As the preceding discussion demonstrates, sociology and the social sciences more generally lack any dominant epistemology (see Turner 2006). The current work thus starts from the premise that academicians teaching in sociology departments often identify epistemologically with one or more of these approaches. To explain the diversity, however, still requires an epistemological anchoring. By setting up the problem as such (see Fuchs 2001), one has committed a priori to a positivist framing commensurate with Homans' (1967) claim that all science has two central tasks: description and explanation. Hence the study starts from the premise that epistemological variation exists in (and beyond) the Canadian context - and can be described accordingly.

Second, what might account for such variation? Despite limited data, various scholars have expressed their views about the forces shaping 
Canadian sociology. For example, Brym (2002) argued that the influx of U. S. academics in the 1960s helped shape the discipline's future in Canada. In particular, many of those migrating northward were radicals or conflict theorists. Eichler (2002) opined further that feminism assumed a more central role in Canadian sociology due to the greater availability of academic positions for women, buttressed by a more prominent feminist movement within Canada. These developments led Brym (2002: 9) to summarize the intellectual landscape of Canadian sociology in these terms:

To be sure, neo-Marxists and feminists do not populate the entire sociological landscape in English Canada. As elsewhere, there was a "cultural turn" in Anglo-Canadian sociology in the 1990s. Substantial pockets of network analysts and symbolic interactionists inhabit various academic departments. Non-radical, quantitative sociologists form a large minority within the sociological community. Nonetheless, neo-Marxist and feminist influences still predominate. ${ }^{10}$

Brym's prescient assessment, however, does not reference much data. More important, if his observations prove accurate, then what would explain that pattern? For example, Warren (2014) shows that in English Canada, most sociologists obtained their highest degrees in the United States up until the mid-1980s. Yet over the past three decades, the majority of those hired into Canadian departments obtained terminal degrees in Canada. One might surmise that the critical roots of sociologists who headed north during the 1960s and 1970s, as well as an increasingly diverse range of voices in the Canadian academy as sociology graduate programs grew, helped shift the epistemological landscape in the critical and feminist directions to which Brym alluded. What other evidence might help substantiate such claims?

In 2009, the CJS devoted an entire issue to "public sociology in Canada." While not an overtly epistemological dialogue, several commentators discuss Burawoy's (2005) critical treatment of four main types of sociology and his defense of public sociology. Helmes-Hayes and McLaughlin (2009) launch the issue with an excellent summary of the historical context of sociology in Canada, as well as key theoretical, normative, and empirical issues under debate. The articles confirm Burawoy's (2009: 885) description of Canada's “disciplinary mosaic," as the spectrum of analyses bespeaks the epistemological diversity of Canadian sociology.

10. As McLaughlin (2004: 81) argued, "Canadian sociology is very much the radical and critical sociology that many internal critics of mainstream sociology in the United States desire." 
Davies (2009) contends that a basic split between "critical" and "mainstream" sociology has intensified over the years, leading to a divided discipline. Creese, McLaren, and Pulkingham (2009: 618) argue further that Burawoy's description of public sociology offers insufficient attention to feminist perspectives, or the manner in which "the vibrant and transformative traditions aligned with feminist sociology... provide a different model of professional critical sociology that engages with diverse publics and social policies." Mesny (2009) claims that despite the nuanced nature of knowledge production in social science, a subversive element persists and the production of knowledge always has a performative quality irreducible to the stark value neutrality that some might advocate. Goldberg and van den Berg (2009) offer a sharp dissent to suggest Canadian sociology has always manifested a public component, despite misgivings about the assumption that the discipline shares a coherent, unified, leftist orientation and the implications of blurring the dividing line between science and advocacy.

Yet only limited data exist to document intellectual pluralism within Canadian sociology. For instance, Brym and Nakhaie (2009) have studied the Canadian professoriate, arguing that the survey evidence conforms to Burawoy's typology: professional scientists constitute less than one-third of the academicians (31.7\%), while critical (24.8\%), policy (24.0\%), and public (19.4\%) intellectuals round out the results. The crude measures and small number of sociologists included, however, undermine a fuller description of the discipline. Their central analytic point, though, remains valid: social backgrounds influence orientations. Those who were females, younger, not married, earning lower salaries, and working in less prestigious institutions were more likely to be public or policy intellectuals compared to professional academics.

In sum, Canadian sociologists are committed to diverse theoretical and methodological approaches (Puddephatt and McLaughlin 2015). ${ }^{11}$ By sociologizing epistemology, one can assess the social origins of their worldviews. The sociologists flooding the Canadian job market in the 1960s and 1970s embodied a generational and demographic transformation of the academy. Those influences still resonate a half century after scholars established themselves across Canada and trained subsequent generations of sociologists. To evaluate these ideas, the paper describes

11. The normative issues as to what sociologists should be doing reflect a divided discipline where distinct paradigms and epistemological orientations have long co-existed (Bhambra, Shilliam, and Orrells 2014; Giri 2006). If anything, paradigmatic approaches, journals, and intellectual outlets have expanded since the 1990s, as scholars have addressed "sociology's history of exclusions in the production of knowledge" (Creese, McLaren, and Pulkingham 2009: 604). 
the results of a nationwide survey of full-time academics in Canadian sociology departments.

\section{Methodology}

To examine the state of Canadian sociology, the author distributed electronic questionnaires to a systematic, random sample of full-time faculty drawn from sociology departments at each university across the country. The questionnaires contained three sections: 1) Demographic Information to capture basic data such as gender, age, education, language, and other background characteristics; 2) Recent Teaching Experience to allow respondents to discuss their teaching perspectives, sense of sociology as a discipline, views about value neutrality in the classroom, and their self-identified mission as a university teacher; and 3) Research Interests, Influences and Areas of Specialization to document their theoretical influences, substantive expertise, main purpose(s) of sociological research, and self-identified methodological approach(es).

Since some scholars were reluctant to complete the lengthier version of the questionnaire $(70 \%$ of the final sample completed the full survey), those who were sampled received a shorter version after three unsuccessful contacts. These surveys omitted the more discursive questions, as well as demographic information that the author could obtain later to fill in the gaps. The current analysis only focuses on items where full demographic data were available and where questions pertaining to teaching and research orientations were asked of all respondents.

The sampling frame consisted of full-time faculty members listed on department websites (verified by administrative staff), or more than 1,000 people identified in Canadian departments with the word sociology in their titles. The author created a spreadsheet with an alphabetical listing, broken down by university, and sent an email request to every third person. Some scholars ended up ineligible for various reasons, such as having recently retired or not actually identifying with sociology (e.g., anthropologists). In those cases, the individuals were replaced with the next person listed. The final response rate of 55.9\% (203/363 surveys) proved consistent with rates obtained from surveys of other professionals (see Burns et al. 2008) and far above the 34\% response rate for Nakhaie's (2007) national survey of The Academic Profession in Canada.

A solid response rate, though, does not ensure sample representativeness. Despite having translated the survey into French, only 35\% of Quebec scholars responded. Three French schools (Laval, UQAM, and UQAR) were underrepresented with a $26.1 \%$ response rate, whereas 
$60 \%$ of those contacted completed the English version. ${ }^{12}$ To test for sample bias, the author compared the demographic information of a random sample of non-respondents with participants. The only significant difference was a lower response rate among Francophone scholars. Since Anglophone and Francophone sociology have been characterized as intellectually independent "solitudes" (Rocher 1990; Jean-Pierre 2013; Warren 2014), the article focuses on the former. Thus the final sample consists of the 190 participants who responded to the English version of the survey.

\section{Results}

The respondents' had a mean age of 52.2 (median 51.5), with an even split between males and females, plus two transgendered individuals. Some $35.3 \%$ were full professors, $41.6 \%$ were associate professors, and $23.2 \%$ were assistant professors or full-time instructors. Just over twothirds were born in Canada, 9.2\% in the U.S., and 23.4\% from countries around the globe. Four in five respondents reported English as their first language, while the remainder spoke any of 19 other languages. Apart from professors born and raised in Quebec and a few from Mexico, all respondents who reported a first language other than English had been born outside of North America. In total, $96.8 \%$ of the sample held doctorates and six individuals held M. A. degrees. Nearly $73 \%$ earned their highest degrees in Canada, one in six from the United States, almost one in ten from England, and the remainder from France, Germany, and Australia. Three-fourths of the respondents held PhD's in sociology, while $24.7 \%$ held degrees in other disciplines.

\section{Empirical Patterns of Epistemological Diversity}

To examine epistemological diversity, the questions assessed respondents' views regarding the distinctiveness of sociology as a science, the main purpose for conducting sociological research, theoretical or paradigmatic influences on their scholarly work, and personal mission statements. These questions helped contextualize the focal question: "Which of the following approaches to methodology most closely approximates your own approach to sociological research? Check all that apply." The author assumed most academicians would have a reasonably

12. The response rates were at least $50 \%$ or higher among English-speaking respondents across most sociology departments, though less than $40 \%$ from members at Carleton University, Kwantlen Polytechnic University, McGill University, and McMaster University. 
clear view of their approaches to studying the social world, i.e., their epistemological frameworks. Indeed, most readily selected from one or more categories: positivism or scientific approach, interpretive social science, critical social science, feminist social science, post-modern or cultural studies approach, and other (specify). More than half (52.1\%) identified only one option as their main research approach. In addition, $23.7 \%$ checked two boxes, $16.3 \%$ checked three boxes, and $7.8 \%$ checked at least four boxes. The cumulative results are summarized in Chart 1. Since respondents selected one or more options, the absolute totals vastly exceed $100 \%$.

\section{Chart 1:}

Percentage Distribution of General Epistemological Orientations $(N=190)$

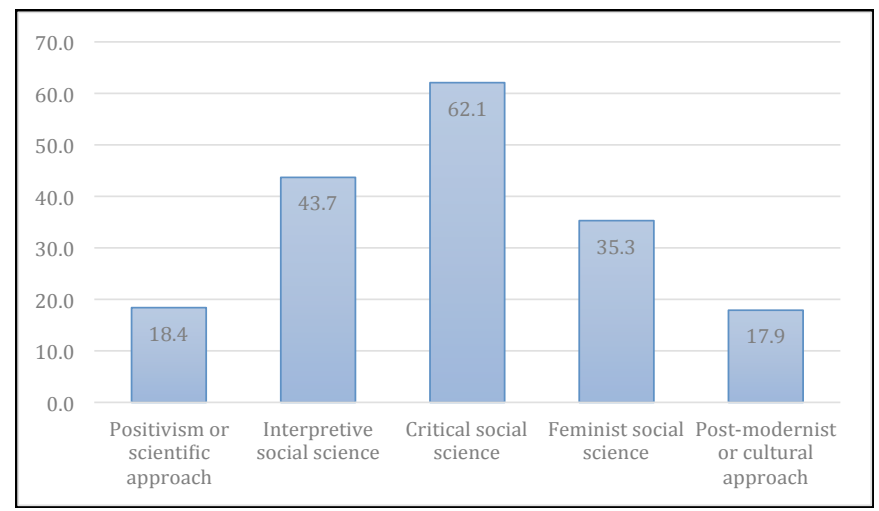

More than $62 \%$ identified critical sociology as at least one of their defining approaches to research. Roughly one-fourth chose the critical social science box alone, but most combined that orientation with feminism, an interpretive approach, or other combinations. Many people further clarified their views regarding the main purpose of sociological research, such as reducing social inequality, promoting social justice, empowering the oppressed, and "changing the world" or "lessening suffering in the world." For example, the following response summarizes how many critical sociologists viewed the central purpose of sociological research: "To produce knowledge with and about subordinate groups and classes in society that will be relevant to improving their life chances; in other words, to produce a better society, one that is more equitable and democratic." Another critical theorist offered a more detailed description of his mission: 
I think my overall 'mission' has to do with helping citizens to see through the veil of mystification that, often powerful, others have erected and reproduced (albeit not always consciously) that is a powerful barrier to needed changes in Canadian society and beyond. My practice around this goal is via teaching, research, student advising, and from time to time community 'engagement.' I try to remain reflective and self-critical in this task, and actively seek debate and discussions with those who disagree with me.

Another common category involved self-described feminist researchers, most often in combination with other approaches to scholarly work such as critical sociology. In total, $85.1 \%$ of those who checked off "feminist social science" also checked off "critical social science." One respondent illustrated her perspective with this comment: "Separating research and politics is not in the interest of oppressed people. The separation of politics (power) and science doesn't exist. Researchers must take their studies into the streets and take part in social actions. This leads to better and more realistic theories." Another feminist scholar defined the core purpose of sociological research as "to explore the social aspects of all types of phenomena, and to do so from a critical perspective that aims for social justice in the broadest possible sense." A third reported that "the most alluring aspect of sociology is to give us tools to study social ills, and also prepare us to suggest ways for social change." In total, about $65 \%$ professed a critical or critical-feminist perspective, with many discussing the issues of social change and social justice.

The respondents identified "interpretive social science" as the second most commonly selected orientation. Nearly $44 \%$ favored at least in part an interpretive or hermeneutic approach to sociological research. One in four of these respondents selected only that specific option. The majority usually merged their interpretive orientation with other perspectives, such as critical and/or feminist approaches. A smaller proportion identified with some elements of "feminist postmodernism," or linked their views with cultural studies more generally.

As expected, interpretive researchers favored the use of the verb "understand" in explaining sociology's main purpose, such as one respondent who hoped "to understand the human condition in a community context." Another stated the general purpose of her perspective as permitting "a more comprehensive understanding of complex social phenomena." Those who combined interpretive and critical traditions were inclined to argue that the main purpose of sociological research should be "to provide a novel and critical way of looking at society." One poetic formulation from a practitioner of interpretive and critical 
social science described the sociological mission accordingly: "The use of history as hindsight to provide insight into the present so that we may gain foresight into the future."

The "positivists" represented $18.4 \%$ of the respondents, including a small number who integrated positivist and interpretive approaches. These scholars defined sociology's main purpose as "description and explanation of social phenomena" or "to expand knowledge and develop comprehensive theories of social life." Those who preferred such a perspective, however, occasionally shared a more activist orientation. For example, one person who bridged positivism and critical approaches explained the main purpose of sociological research thusly: "To gain greater understanding of and insights into society with a goal (of) contributing to knowledge for the sake of a better society." Finally, a few respondents expressed discomfort with the connotations of the term "positivism," preferring to characterize their research as historical or quantitative - but with a clear commitment to "scientific sociology."

Just under $18 \%$ of study participants explicitly identified themselves as adherents of post-modernism, poststructuralism, or cultural studies. Nearly all of these individuals combined their epistemological leanings with critical, feminist, and/or interpretive frames of reference as well. One person offered this description of the sociological mission: "To produce research and teaching which will increase critical understanding of sociocultural reality and relations of power and how our subjectivities are constituted." Another stated that the mission involved "push(ing) students to think in new ways and to resist the McDonaldization of education."

The evidence highlights the importance of examining further the conceptualization of epistemological diversity and the manifold combinations of approaches identified. By combining respondents' descriptions of preferred methodological orientations with their more general approaches to knowledge-building and dissemination, a more nuanced picture emerges of how respondents define their epistemological orientations. ${ }^{13}$ These results appear in Chart 2.

13. The answers to the question about preferred methodological approaches were cross-referenced with responses to the questions as to their views of the main purpose of sociological research, main intellectual influences, and "personal mission statement as a member of a Canadian sociology department." If there were still uncertainties regarding their orientations, the author then examined respondents' publications to further clarify their epistemological views. 


\section{Chart 2:}

Percentage Distribution of Specific Epistemological Orientations $(N=190)$

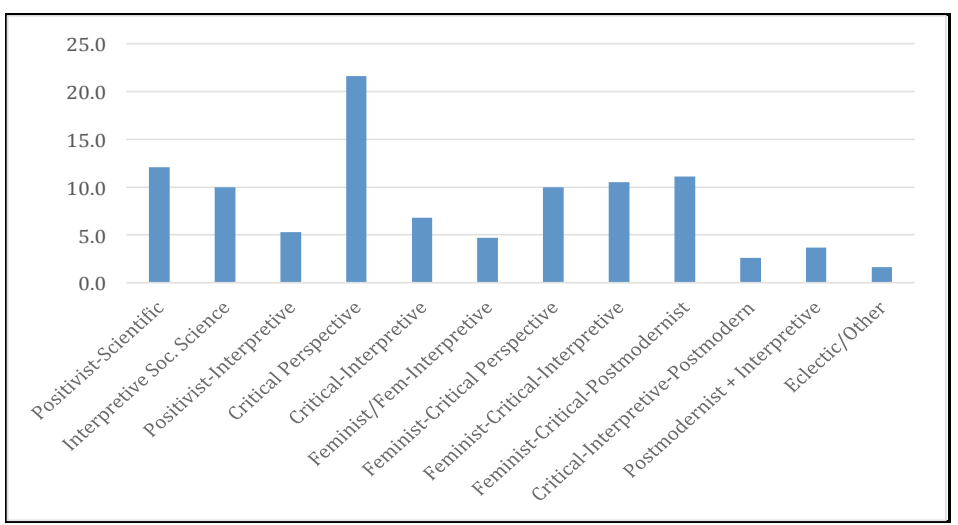

The evidence indicates that the single largest category consisted of the more than one in five respondents who identified exclusively with a "critical social science" orientation. Among the many possible examples, one critical theorist explained the position accordingly: "The purpose of sociological research is to engage critically with our social reality in order to produce new knowledges and paths of social change... Ideally, though, all sociological research engages with the pressing social, moral, ethical, economic and cultural issues of the day."

An additional $6.8 \%$ identified the combination of critical and interpretive perspectives to frame their epistemologies: "I use symbolic interaction, but also the critical perspective and I'm now moving towards intersectional analysis." Another respondent explained, "A critical interpretive perspective acknowledges the positioned, partial and partisan nature of all knowledge." Later in the survey, that same individual stated that "I support a value-informed sociological practice which is endeavouring to change the world, i.e. challenge oppression and exploitation. To do otherwise is to tacitly support the status quo."

Many respondents combined feminist and critical perspectives, often with interpretive or post-modernist orientations as well. For example, one participant described her approach as "feminist critical realism," stressing the need to "link sociology to ideas about social justice." Another identified the main purpose of research as "a means of questioning, challenging and resisting the dominant discourses in which we are always enmeshed." With a commitment to feminism, constructivism, and post-structuralism, that person stressed the need to "critically understand the society in which you live (and) the position of your own 'self' within that society. That 
requires a life-long commitment to the search for 'truth' which opposes contemporary relations of power, situated in dominant discourses."

Among the one in ten participants who claimed an adherence to a "critical-feminist-postmodernist" perspective, one framed the approach as follows: "To offer understanding and critique. Understanding-pursued in the full sense of the term - is by definition critique. The goal is not to create new ideas or new knowledge, but to reflect upon the make-up of the social worlds in which we already live." Another 7\% defined themselves as operating within a post-modernist framework primarily, with secondary linkages to either critical/feminist or interpretive theory. For example, one respondent stated: "I have drawn from Foucaultian paradigms, feminist paradigms, post-modern paradigms, and also interdisciplinary paradigms (in my studies)."

About one in ten preferred an interpretive framework exclusively, while an additional $5.3 \%$ viewed themselves as integrating positivism and interpretive sociology. One professor who adheres solely to an interpretive approach explained her position: "To contribute to the larger (not just Canadian) discussion of sociological theory (and) to help Canadian students...to be able to understand society better, and how they can relate to society in a way that can be both meaningful for them and positive for society." Similarly, a respondent committed to interpretive sociology and phenomenology aspired to "demonstrate to students a sociological understanding of the world... to see past the individualism and psychologism inherent in most university education... My hope is to encourage in students a deep reflection and understanding of their selves and others." A third individual sympathetic to both positivist and interpretive frameworks stated that "I attempt to produce empirically-grounded, theoretically rich work that draws on a range of methodologies to help us better understand our political ecology."

Another $12.1 \%$ subscribed exclusively to a positivist or scientific orientation. These respondents typically identified the purpose of sociological research simply as to "explain the world" or, in another case, "to further the advancement of scientific knowledge of the social world." A survey research specialist succinctly defined the main objective of sociological research as "to advance knowledge." One self-described "scientist" outlined his personal approach as follows:

I do not dogmatically adhere to any particular theoretical perspective. My research tends to focus on answering specific research questions through an empirical examination of causal mechanisms. With any research question, I try to examine all relevant theoretical explanations and determine which ones, if any, are supported by the empirical evidence. 
Some analysts preferred postmodernist frameworks, usually combined with critical and/or interpretive perspectives. One postmodernist described her research as "post-structural discourse analysis," with special interests in communications and media history. An interpretivepostmodernist adherent suggested that the core of sociological research involved "being in a position to enter social and cultural worlds from the vantage point of curiosity about change, acquiring insights into the dynamics of everyday life." Furthermore, "the purpose clearly is to bring these insights into a debate that needs to have the capacity to have us constantly contemplate our human condition and the challenges and risks we face."

A smattering of other responses usually included a critical dimension, even if the respondents refused to place themselves in the boxes provided. One scholar viewed the main purpose of sociological research as follows: “In Elias's terms, to 'destroy social myths' and pursue grounded empirical understandings of how the world is socially constructed by deeply connected agents enmeshed in long chains of social interdependence. To expose members of our society to the social processes which bind us together, and evidence the power of human agency." Another respondent elaborated with the following comment:

This question takes me back to the earlier questions on value neutrality. I believe sociology is an inherently moral discipline engaged in the pursuit of truth, justice, equity, fairness, and a better (social) world. While it is important to be as value neutral as is possible in this pursuit, sociology is a moral enterprise. The main purpose of sociological research is to pursue worthy goals.

\section{Explaining Epistemological Variation}

At the descriptive level, the responses confirmed Brym's (2002) claims about the predominance of critical and feminist orientations among those populating Canadian sociology departments. More than three-fifths reported a critical perspective exclusively or in combination with a feminist orientation. Hence the most common orientations within Anglo-Canadian sociology embraced variations of the critical social science perspective, though usually with linkages to feminist, interpretive, and occasionally post-modernist frameworks.

By cross-referencing the methodology question with other survey items (questions about value neutrality, the nature of sociology as a distinct discipline, main theoretical influences, and main objective of sociological research), a more definitive snapshot of epistemological orientations emerged. These questions helped confirm the characterization of the 
clear majority of respondents as critical scholars, wherein their self-labels and commentaries indicated an interest in changing the world through myriad forms of critique, scholarship, teaching, activism, and/or possibly public engagement. The final issue, then, involves examining why critical and feminist perspectives predominate, rather than any of the other possible contenders.

From a sociological perspective, the prevalence of the critical orientation reflects the social locations of the academicians who populate Canadian sociology departments. The long-term progression has been that as the academy has diversified, theoretical pluralism has increased as well. Two trends in particular cast some light upon the Canadian experience. As previously noted, the Canadianization movement helped establish a distinctive intellectual flavor, if not always an outright rejection of the presumably more positivistic orientations of American sociologists. Furthermore, one might hypothesize that those groups historically underrepresented in the academy (e.g., women, minorities) might frame their research in diverse and often critical ways. In fact, a generation of intellectuals - baby boomers and transplanted Americans in the Vietnam era-secured tenure-track appointments in an era of rapid intellectual diversification in the academy. As a result, several leading feminist and critical scholars have populated Canadian universities and their messages should have filtered through to graduate students. Ergo a critical core should have dominated Canadian sociology during the 1970s and 1980s, as well as in educating the next generation of sociological scholars. These data confirm such a trend.

For example, a logistic regression model helped predict which academicians were more likely to identify as having a critical or criticalfeminist orientation. As reported in Table 2, women and transgendered individuals were more than three times as likely compared to men to hold such a perspective. Second, the more senior cohort (aged fifty and older) were three and one half times more likely than younger cohorts to espouse these views. Third, those who obtained their degrees in Canada were twice as likely to have such a perspective in comparison with those who obtained their PhDs elsewhere. Finally, those who obtained degrees in disciplinary genres other than sociology were more than twice as likely to have critical or critical-feminist perspectives as those with PhD's in sociology. These four variables combined to explain about $22 \%$ of the variation in whether one self-identified as a critical or critical-feminist scholar. $^{14}$

14. One reviewer inquired about race/ethnicity and sexual orientation, but these were not measured in the survey. Consistent with the current analysis, though, one might hypothesize that more marginalized scholars (holding minority statuses) are more likely to assume critical stances. 
Table 2: Factors Associated with Critical-Feminist Views

\begin{tabular}{|l|c|}
\hline Independent Variables & Odds Ratios \\
\hline $\begin{array}{l}\text { Geography (Non-Canadian University }=\text { ref.) } \\
\text { Canadian University }\end{array}$ & $2.30^{*}$ \\
$\begin{array}{l}\text { Gender (Male }=\text { ref.) } \\
\text { Female/Transgendered }\end{array}$ & $3.42^{* * *}$ \\
$\begin{array}{l}\text { Generation (50 Years or Younger }=\text { ref.) } \\
\text { Over 50 Years in Age }\end{array}$ & $3.56^{* * *}$ \\
$\begin{array}{l}\text { Genre (Degree in Sociology }=\text { ref.) } \\
\text { Non-Sociology PhD }\end{array}$ & $2.15^{*}$ \\
Constant & $0.24 * *$ \\
\hline $\begin{array}{l}-2 \text { Log likelihood }=227.667 \\
\text { Nagelkerke Pseudo } \mathrm{R}^{2}=.22\end{array}$ \\
\hline$* \mathrm{p}<.05, * * \mathrm{p}<.01, * * * \mathrm{p}<.001$ & \\
\hline
\end{tabular}

Thus four "g" factors - gender, generation, geography, and genre- explain a substantial portion of the variation in epistemological orientations among full-time academics in Canadian sociology departments. While there are many nuances, the dominant framework consists of an overall critical approach often aligned with feminist orientations. From a qualitative perspective, the main narratives that respondents expressed in both teaching and research emphasized the importance of utilizing or instilling a critical and frequently "social justice" orientation in their diffuse forms of academic engagement. Although the questionnaire did not contain the term "social justice" in any of the wording, more than three dozen study participants used the concept in articulating their responses.

For example, a female professor defined her personal mission statement as a member of a Canadian sociology department simply as "contribut(ing) to the pursuit of social justice." A second respondent elaborated on the theme: "Sociology should be the study of society with the expressed aims of ameliorating social conflicts and striving for social justice. Attendant research and teaching activities should then be about developing tools and methods for social analysis and promoting such consciousness and awareness." A third respondent reiterated the idea in stating that "I think it's important to link sociology to ideas about social justice."

In regard to the question about one's "teaching mission," one participant offered an elegant summary: "To change minds; to make the lives of younger people easier by providing them with a critical perspective on the world around them; (and) to not be 'value neutral' but demon- 
strate quite the opposite, that courageous beliefs and political passion for social justice matter." Another professor defined his teaching mission in part with these words: "It is important that (students) reflect on and challenge discriminatory ideas to the point will they become eventual agents of egalitarian social change associated with social and political movement." Another expressed her teaching mission succinctly as that of "build(ing) students' capacities as sociologists committed to working for social justice."

Apart from their views on teaching, the comments on the main purpose of sociological research and in regard to personal mission statements expanded further on the social justice theme. Several examples help to substantiate the point:

- “(A)s a health sociologist, I am interested in social justice issues and in working towards making peoples' lives 'better' through the sharing of information between disciplines."

- "Research is the companion to teaching - share similar goals - research to promote social justice and develop finer analysis of social processes that produce injustices. Also we need to translate academic knowledge to everyday world of community politics, governance etc."

- "Most of my work is focused on social justice issues, broadly speaking, so my main aim is to generate accurate and useful knowledge about inequalities and oppressions in our contemporary world."

- "To foster amongst my students and my colleagues through my research and teaching an improved awareness of the pressing social justice issues facing Canadian society as well as societies around the globe."

- "To challenge mainstream thinking and promote social justice."

- "Advancing our understanding of social issues in ways that support social justice initiatives."

Several respondents further supported having a more activist orientation as sociologists. For example, one critical-feminist-postmodernist noted: "My 'mission', broadly speaking, is to leave an anti-violence legacy, whether from symbolic, structural, normal, interpersonal, etc, but particularly from penal and colonial analysis. My teaching, research and service activities revolve around this." Another person remarked: 
Much of my work involves community engagement. I do a lot of public lectures and my research integrates insights garnered from unions, community activists, and the public. I am widely described as a 'public intellectual,' an accolade of which I am proud as I view it is an essential part of my role and a social commitment to which everyone privileged to work at a university should uphold.

A post-modernist thinker with critical-interpretive sympathies articulated her position in these words: "Sociology should be equally informing public debate (social field) as much as shaping the academic field, such as through public sociology, collaborative research methods, social movements, research contracts, etc." Still another individual expressed with enthusiasm the idea of a more engaged type of public sociology: "Sociology is increasingly shifting its focus to social issues in local communities, as well as at societal levels...I'm impressed by this practical, community-oriented focus, which holds much promise for both the public acceptance and knowledge of the discipline, but also for sociology's role in participating with policy-makers and community activists to construct a more inclusive society."

Some participants discussed as well concerns about the "Americanization" of Canadian institutions. One critical-feminist-postmodernist, for example, defined her mission to "(a)dvance a specifically Canadian sociology." A Marxist-interpretive analyst considered his main purpose in conducting research as "fill(ing) in the story of the development of sociology in Canada." In contrast, a female sociologist with a positivistinterpretive bent offered an interesting dissent to that view: "I realize that Canada is a small country and if scholars here don't study it, its issues won't be addressed. But I feel a pressure by some members of my department to focus on Canada, and I see this as a hindrance to the intellectual freedom that creates truly great departments and scholarship." In fact, one Canadian academic explained via email to having left for a tenure-track position in the U. S. "because I am a quantitative researcher. I often felt that this type of research was not valued (there). To be honest, I don't think quantitative work is valued much at most Canadian universities-too positivistic for most."

Less than $5 \%$ of the respondents, though, expressed any concerns about the critical leanings of their colleagues, or otherwise endorsed fervidly a more scientific approach to social analysis. Yet those who held such positions clearly stood out from the dominant narrative. For example, one respondent expressed the contrarian opinion that "far too many so-called 'sociologists' are mainly ideologues, social activists, or simply pedestrian thinkers at best. The majority do not seem to be excited about or interested in the scientific study of human behaviour... They 
are hopelessly lost in pursuing various missions that have, for the most part, nothing to do with scientific inquiry." Indeed, some commentators shared impassioned pleas to pursue the "scientific ideal" in their work and teaching. One young scholar remarked accordingly: "My passion is teaching students how to engage with the world empirically. I want them to be able to design and execute empirical research projects (and) have an empirical and social scientific mindset. In order to do that, my courses require students to do real empirical work, whether qualitative, quantitative, or structural (i.e. networks)."

\section{Conclusions}

The national survey results confirm what many have assumed about Canadian sociology. First, there exists tremendous epistemological diversity. Second, the perspectives are neither randomly nor evenly distributed. At least within Canada, there exists a widespread critical core to the sociological enterprise that a majority of scholars practices, with different and yet often overlapping emphases (e.g., feminism, anti-colonialism, anti-racism, intersectionality, social justice, etc.). The critical core reflects in part the social locations of sociological practitioners. The results determined that the greater proportion of women comprising sociology departments, the generational effects of those who achieved tenure in the latter part of the $20^{\text {th }}$ century, and the educational experiences of those receiving PhDs in Canada have contributed to broad support for critical and feminist approaches in Canadian sociology programs.

In some cases, the sociology departments explicitly advocate for a social justice mission and orientation. For example, Brock University has committed fully to an epistemological divorce (see Davies 2009; Turner 2005) by embracing critical sociology exclusively, including an "M. A. in Critical Sociology." Their website opens with the following statement: "The Department of Sociology at Brock University is committed to a critical, social justice approach." Similarly, York University's website announces their "Public Sociology" orientation as follows: "Our department's contribution to the world of sociological thought and research is to offer our students a sociology of engagement; a critical approach to scholarship that challenges assumptions, and in so doing, aims for greater social justice and an appreciation that history - our own and that of others around the world - has a lasting impact on the present." These are interesting perspectives, especially if one subscribes to Tindall's (2014) argument that the predominance of certain intellectual 
orientations serves as a critical fault line in terms of departmental hiring practices, graduate instruction, and shaping the future of discipline.

In addition to the critical nucleus, the interpretive and positivist traditions both claim significant minorities in Canadian sociology departments. The postmodernist, cultural studies, and assorted other perspectives co-exist to a more limited degree. The relative proportions of scholars who embrace different epistemological frameworks obviously vary across institutions. Yet the critical core exists nearly everywhere across the Canadian academic landscape, just as Brym (2002) and McLaughlin (2004) asserted over a decade ago. Roughly $90 \%$ of the departments in the current study claimed at least a significant minority of critical-feminist researchers (minimum of one-third of their respondents). At least half of the participants from most departments identified with some version of critical or critical-feminist orientations. The rare exceptions where less than one-third of the respondents identified as critical-feminist researchers came from universities with fewer respondents, such as McGill, which touts their historical contributions to establishing "empirical sociology in Canada" on their website. ${ }^{15}$ Only one or two respondents were sampled from some of the smaller universities, which thereby undermines any ability to generalize these results at the departmental level.

Future research will expand on these themes by investigating the social and generational roots of the epistemological pluralism described, as well as by examining further the theoretical frameworks within which Canadian sociologists position their scholarly work. Another approach involves studying epistemological issues in greater depth at the departmental level, which ideally moves beyond the academicians' personal responses to consider course content, publications, and program requirements at the undergraduate and graduate levels. One final aspect involves a comparative analysis of sociologists' epistemological orientations in both Canada and the United States. Based on current patterns and the responses evaluated thus far, the evidence points to a continuation of the observed epistemological diversity and a sustained predominance of critical and feminist orientations for the foreseeable future.

15. Websites offer fascinating glimpses of the sociological worlds that departments define for themselves. The University of Toronto's website, for instance, does not mention any particular epistemological frameworks, but rather states: "We are proud that our vibrant department is consistently the top-ranked Sociology Department in Canada, with internationally-renowned scholars who have an excellent track record for securing research funding, producing outstanding sociological research, and extensively mentoring our graduate students." 


\section{REFERENCES}

Abend, Gabriel. 2006. Styles of sociological thought: Sociologies, epistemologies, and the Mexican and U. S. quests for truth. Sociological Theory 24(1): 1-41.

Adorno, Theodor W. 1973. Negative Dialectics. New York: The Seabury Press.

Alcoff, Linda and Elizabeth Potter, eds. 1993. Feminist Epistemologies. New York: Routledge.

Andrew, Caroline. 1995. Ethnicities, citizenship and feminisms: Theorizing the political practices of intersectionality. Nationalism and Ethnic Politics 1(3): 64-81.

Antonio, Robert J. 1981. Immanent critique as the core of critical theory: Its origins and developments in Hegel, Marx, and contemporary thought. British Journal of Sociology 32(3): 330-345.

Ashman, Keith M. and Philip S. Baringer, eds. 2001. After the Science Wars. London: Routledge.

Azmanova, Albena. 2012a. Social justice and varieties of capitalism: An immanent critique. New Political Economy 17(4): 445-463.

Azmanova, Albena. 2012b. De-gendering social justice in the $21^{\text {st }}$ century: An immanent critique of neoliberal capitalism. European Journal of Social Theory 15(2): 143-156.

Bakker, J. I. (Hans). 2011. Pragmatic sociology: Healing the discipline. Sociological Focus 44(3): 167-183.

Berger, Peter L. and Thomas Luckmann. 1966. The Social Construction of Reality: A Treatise on the Sociology of Knowledge. Garden City, NY: Doubleday.

Bhambra, Gurminder K., Robbie Shilliam, and Daniel Orrells. 2014. Contesting imperial epistemologies. Journal of Historical Sociology 27(3): 293-301.

Bhaskar, Roy. 1975. A Realist Theory of Science. Leeds: Leeds Books.

Black, Donald. 1995. The epistemology of pure sociology. Law and Social Inquiry 20(3): 829-870.

Brym, Robert J. 2002. Canadian sociology: An introduction to the upper thirteen. The American Sociologist 33(1): 5-11.

Brym, Robert J. and M. Reza Nakhaie. 2009. Professional, critical, policy, and public academics in Canada. Canadian Journal of Sociology 34(3): 655669.

Burawoy, Michael. 2005. For public sociology. American Sociological Review 70(1): 4-28.

Burawoy, Michael. 2009. Disciplinary mosaic: The case of Canadian sociology. Canadian Journal of Sociology 34(3): 869-886. 
Burns, Karen, Mark Duffett, Michelle Kho, Maureen Meade, Neill Adhikari, Tasnim Sanuff, and Deborah Cook. 2008. A guide for the design and conduct of self-administered surveys of clinicians. Canadian Medical Association Journal 179(3): 245-252.

Carr, Wilfred and Stephen Kemmis. 1986. Becoming Critical: Education, Knowledge, and Action Research. London: Falmer Press.

Clark, Samuel D. 1975. Sociology in Canada: An historical over-view. Canadian Journal of Sociology 1(2): 225-234.

Clark, Samuel D. 1979. The changing image of sociology in English-speaking Canada. Canadian Journal of Sociology 4(4): 393-403.

Clement, Wallace. 1977. Macrosociological approaches toward a Canadian sociology. Alternative Routes 1(1): 1-37.

Code, Lorraine. 1993. Taking subjectivity into account. In Feminist Epistemologies, edited by L. Alcoff and E. Potter, 15-48. New York: Routledge.

Cole, Stephen. 2006. Disciplinary knowledge revisited: The social construction of sociology. American Sociologist 37(2): 41-56.

Coleman, James. 1990. Foundations of Social Theory. Cambridge, MA: Harvard University Press.

Colfax, J. David and Jack L. Roach, eds. 1971. Radical Sociology. New York: Basic.

Collins, Patricia Hill. 2000. Black Feminist Thought: Knowledge, Consciousness, and the Politics of Empowerment (second edition). New York: Routledge.

Collins, Randall. 1986. Is 1980s sociology in the doldrums? American Journal of Sociology 91: 1336-1355.

Cormier, Jeffrey. 2004. The Canadianization Movement: Emergence, Survival, and Success. Toronto: University of Toronto Press.

Cormier, Jeffrey. 2005. The Canadianization movement in context. Canadian Journal of Sociology 30(3): 351-370.

Creese, Gillian, Arlene Tigar McLaren, and Jane Pulkingham. 2009. Rethinking Burawoy: Reflections from Canadian feminist sociology. Canadian Journal of Sociology 34(3): 601-622.

Curtis, Bruce and Lorna Weir. 2002. The succession question in English Canadian sociology. Society-Societe 26(3): 3-13.

Davies, Scott. 2009. Drifting apart? The institutional dynamics awaiting public sociology in Canada. Canadian Journal of Sociology 34(3): 623-654.

DeVault, Marjorie L. 1999. Liberating Method: Feminism and Social Research. Philadelphia: Temple University Press.

Eichler, Margrit. 1985. And the work never ends: Feminist contributions. Canadian Review of Sociology and Anthropology 22(5): 619-644. 
Eichler, Margrit. 2002. The impact of feminism on Canadian sociology. The American Sociologist 33(1): 27-41.

Ericson, Richard, Andrew Harrell, Lyle Larson and Nico Stehr. 1975. Editorial. Canadian Journal of Sociology 1(1): vi-vii.

Felt, Lawrence. 1975. Nationalism and the possibility of a relevant Anglo-Canadian sociology. Canadian Journal of Sociology 1(3): 377-385.

Feyeraband, Paul. 1975. Against Method: Outline of an Anarchistic Theory of Knowledge. London: Atlantic Highlands, Humanities Press.

Foucault, Michel. 1998. Aesthetics, Method, and Epistemology (edited by James D. Faubion). New York: New Press.

Fuchs, Stephan. 1993. Three sociological epistemologies. Sociological Perspectives 36(1): 23-44.

Fuchs, Stephan. 2001. Against Essentialism: A Theory of Culture and Society. Cambridge, MA: Harvard University Press.

Fuller, Steve. 1993. Philosophy of Science and its Discontents. New York: Guilford Press.

García, J. Roberto. 2015. Using a critical race praxis to examine and resist the discursive practices that reproduce racism, misogyny, and homophobia. Qualitative Inquiry 21(3): 315-323.

Gingras, Yves. 2010. The end of the Canadianization movement: A globalization by-product? University Affairs (November 8). Accessed at: http://www. universityaffairs.ca/opinion/ in-my-opinion/end-of-the-canadianizationmovement (January 24, 2016).

Giri, Ananta Kumar. 2006. Creative social research: Rethinking theories and methods and the calling of an ontological epistemology of participation. Dialectical Anthropology 30(3-4): 227-271.

Goldberg, Avi and Axel van den Berg. 2009. What do public sociologists do? A critique of Burawoy. Canadian Journal of Sociology 34(3): 765-802.

Gouldner, Alvin W. 1970. The Coming Crisis of Western Sociology. New York: Basic Books.

Harding, Sandra. 1986. The Science Question in Feminism. Ithaca, NY: Cornell University Press.

Harding, Sandra. 1991. Whose Science? Whose Knowledge? Thinking from Women's Lives. Ithaca, NY: Cornell University Press.

Haynor, Anthony L. and Joseph A. Varacalli. 1993. Sociology's fall from grace: The six deadly sins of a discipline at the crossroads. Quarterly Journal of Ideology 16(1-2): 3-29.

Held, David. 1980. Introduction to Critical Theory: Horkheimer to Habermas. Berkeley: Berkeley University Press. 
Helle, Horst J. 1991. Verstehen and Pragmatism: Essays in Interpretive Sociology. Frankford, Germany: Peter Lang.

Helmes-Hayes, Rick and Neil McLaughlin. 2009. Public sociology in Canada: Debates, research, and historical context. Canadian Journal of Sociology 34(3): 573-600.

Hempel, Carl G. 1965. Aspects of Scientific Explanation, and Other Essays in the Philosophy of Science. New York: Free Press.

Hiller, Harry H. 1979. The Canadian sociology movement: Analysis and assessment. Canadian Journal of Sociology 4(2): 125-150.

Hiller, Harry H. 1980. Paradigmatic shifts, indigenization, and the development of sociology in Canada. Journal of the History of the Behavioral Sciences 16: 263-274.

Homans, George C. 1967. The Nature of Social Science. New York: Harcourt, Brace and World.

Hughes, John. 1980. The Philosophy of Social Research. New York: Longman.

Hunter, Alfred A. 1985. Doing it with numbers. Canadian Review of Sociology and Anthropology 22(5): 645-672.

Husserl, Edmund. 1960. Cartesian Meditations: An Introduction to Phenomenology. The Hague: M. Nijhoff.

Huttunen, Rauno and Mark Murphy. 2012. Discourse and recognition as normative grounds for radical pedagogy: Habermasian and Honnethian ethics in the context of education. Studies in Philosophy and Education 31: 137-152.

Intemann, Kristen. 2010. 25 years of feminist empiricism and standpoint theory: Where are we now? Hypatia 25(4): 778-796.

Jackson, John. D. 1985. Introduction. Canadian Review of Sociology and Anthropology 22(5): 615-618.

Jean-Pierre, Johanne. 2013. Teaching sociology of education in Canada: A comparative study of the two solitudes. International Studies in Sociology of Education 23(1): 39-55.

Latour, Bruno. 1987. Science in Action. Cambridge: Harvard University Press.

Laudan, Larry. 1990. Science and Relativism: Some Key Controversies in the Philosophy of Science. Chicago: University of Chicago Press.

Lazarsfeld, Paul and Morris Rosenberg, eds. 1955. The Language of Social Research: A Reader in the Methodology of Social Research. New York: Free Press.

Longino, Helen. 2010. Feminist epistemology at Hypatia's $25^{\text {th }}$ anniversary. Hypatia 25(4): 733-741.

Luxton, Meg. 1980. More than a Labour of Love: Three Generations of Women's Work in the Home. Toronto: Women's Educational Press. 
Lyotard, Jean-François. 1984. The Postmodern Condition: A Report on Knowledge. Minneapolis: University of Minnesota Press.

Mannheim, Karl. (1929)1966. Ideology and Utopia: An Introduction to the Sociology of Knowledge. New York: Harcourt, Brace, and World.

Marchak, Patricia. 1985. Canadian political economy. Canadian Review of Sociology and Anthropology 22(5): 673-709.

Matthews, Ralph. 2014. Committing Canadian sociology: Developing a Canadian sociology and a sociology of Canada. Canadian Review of Sociology 51(2): 107-127.

McLaughlin, Neil. 2004. A Canadian rejoinder: Sociology north and south of the border. The American Sociologist 35(1): 80-101.

McLaughlin, Neil. 2014. Canadian uniqueness and theoretical-methodological pluralism in Sociology. Canadian Review of Sociology 51(4): 402-408.

Mesny, Anne. 2009. What do 'we' know that 'they' don't? Sociologists' versus nonsociologists' knowledge. Canadian Journal of Sociology 34(3): 671695.

Michalski, Joseph H. 2008. Scientific discovery in deep social space: Sociology without borders. Canadian Journal of Sociology 33(3): 521-553.

Morrow, Raymond A. 1985. Critical theory and critical sociology. Canadian Review of Sociology and Anthropology 22(5): 710-747.

Morrow, Raymond A. 1991. Introduction: The challenge of cultural studies to Canadian sociology and anthropology. Canadian Review of Sociology and Anthropology 28(2): 153-172.

Nakhaie, M. Reza. 2007. Universalism, ascription and academic rank: Canadian professors, 1987-2000. Canadian Review of Sociology and Anthropology 44: 361-386.

Nash, Jr., Bradley and Mark Wardell. 1993. The control of sociological theory: In praise of the interregnum. Sociological Inquiry 63(3): 276-292.

Neuman, W. Lawrence. 2006. Social Research Methods: Qualitative and Quantitative Approaches (sixth edition). Boston: Pearson.

Nielsen, Greg M. 1991. Cultural studies, a sociological poetics: Institutions of the Canadian imaginary. Canadian Review of Sociology and Anthropology 28(2): 279-298.

O’Neill, John. 1985. Phenomenological sociology. Canadian Review of Sociology and Anthropology 22(5): 748-770.

Phillips, Bernard S. 2001. Beyond Sociology's Tower of Babel: Reconstructing the Scientific Method. New York: Aldine de Gruyter.

Platt, Jennifer. 2006. How distinctive are Canadian research methods? Canadian Review of Sociology and Anthropology 43(2): 205-231. 
Popper, Karl. 1934. Scientific method. In Popper Selections, edited by D. Miller, 133-142. Princeton, NJ: Princeton University Press.

Puddephatt, Antony J. and Neil McLaughlin. 2015. Critical nexus or pluralist discipline? Institutional ambivalence and the future of Canadian sociology. Canadian Review of Sociology 53(2): 310-332.

Reed, Isaac and Jeffrey C. Alexander. 2009. Social science as reading and performance: A cultural-sociological understanding of epistemology. European Journal of Social Theory 12(1): 21-41.

Richardson, R. Jack and Barry Wellman. 1985. Structural analysis. Canadian Review of Sociology and Anthropology 22(5): 771-793.

Ritzer, George. 1975. Sociology: A Multiple Paradigm Science. Boston: Allyn and Bacon.

Rocher, Guy. 1990. The two solitudes among Canadian sociologists. SocietySociete 14(3): 3-4.

Rorty, Richard. 1979. Philosophy and the Mirror of Nature. Princeton, NJ: Princeton University Press.

Rorty, Richard. 1991. Objectivity, Relativism and Truth: Philosophical Papers. Volume 1. Cambridge: Cambridge University Press.

Rosenberg, Alexander. 1986. Philosophy of science and the potentials for knowledge in the social sciences. In Metatheory in Social Science: Pluralisms and Subjectivities, edited by D. W. Fiske and R. A. Shweder, 339-346. Chicago: University of Chicago Press.

Schutz, Alfred. 1967. The Phenomenology of the Social World. Evanston, IL: Northwestern University Press.

Siedman, Steven. 1991. The end of sociological theory: The postmodern hope. Sociological Theory 9(2): 131-146.

Siedman, Steven, ed. 1994. The Postmodern Turn. Cambridge: Cambridge University Press.

Smith, Dorothy. 1975. What it might mean to do a Canadian sociology: The everyday world as problematic. Canadian Journal of Sociology 1(3): 363-376.

Smith, Dorothy E. 2005. Institutional Ethnography: A Sociology for People. Walnut Creek, CA: AltaMira Press.

Tanesini, Alessandra. 1999. An Introduction to Feminist Epistemologies. Oxford: Blackwell.

Tindall, D. B. 2014. A distinctive Canadian sociology? Canadian Review of Sociology 51(4): 395-401.

Thompson, Michael J. 2014. The base-superstructure hypothesis and the foundations of critical theory. Current Perspectives in Social Theory 32: 161193. 
Turner, Jonathan H. 1989. The disintegration of American sociology. Sociological Perspectives 32: 419-433.

Turner, Jonathan H. 2001. Sociological theory today. In Handbook of Sociological Theory, edited by J. H. Turner, 1-17. New York: Kluwer Academic/ Plenum Publishers.

Turner, Jonathan H. 2005. Is public sociology such a good idea? The American Sociologist 36(3-4): 27-45.

Turner, Jonathan H. 2006. American sociology in chaos: Differentiation without integration. The American Sociologist 37(2): 15-29.

Turner, Stephen P. and Jonathan H. Turner. 1990. The Impossible Science: An Institutional Analysis of American Sociology. Newbury Park, CA: Sage.

Warren, Jean-Philippe. 2014. The end of national sociological traditions? The fates of sociology in English Canada and French Quebec in a globalized field of science. International Journal of Canadian Studies 50: 87-108.

Joseph H. Michalski teaches in the Department of Sociology, King's University College at Western University. His interests include the development of sociological theory and the sociology of knowledge, as well as comparative studies of domestic violence, terrorism, conflict management, and crime-related issues. He also conducts research on the issues of poverty, precarious work, and social inequality.

jmichal2@uwo.ca 